Katarzyna Czernic

\section{Ile trzeba mieć lat, żeby być starym?}

DOI: http://dx.doi.org/10.12775/LC.2018.011

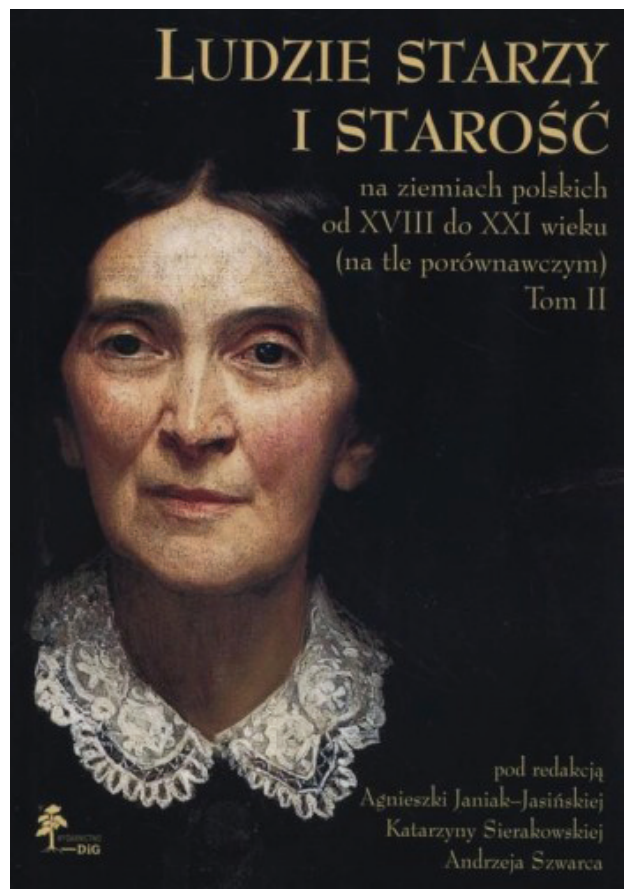

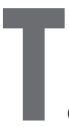

ematyka starości wydaje się szturmem wkraczać $\mathrm{w}$ przestrzeń zainteresowania współczesnych badaczy, skoro na przestrzeni czterech tylko lat doczekaliśmy się kilku monografii, tomów prac zbiorowych ${ }^{1}$ oraz

\footnotetext{
Doktorantka w Zakładzie Literatury Polskiej Romantyzmu i Pozytywizmu Instytutu Literatury Polskiej Uniwersytetu Mikołaja Kopernika w Toruniu. E-mail: katarzyna.czernic@gmail.com.

1 Warto wymienić oprócz recenzowanej pozycji następujące publikacje: Szatur-Jaworska, Barbara 2016. Polska polityka społeczna wobec starzenia się ludności w latach 1971-2013. Warszawa: Elipsa Dom Wydawniczy; Stawiak-Ososińska, Małgorzata, Agnieszka Szplit (red.) 2014. Historyczno-społeczne aspekty starzenia się $i$ starości. Kielce: Agencja
}

wielu artykułów. Jak zauważa Norbert G. Piguła: „zasadne jest podejmowanie kwestii starzenia się społeczeństw jako wyzwania dla jednostki, grupy oraz całego społeczeństwa” (Piguła 2015: 8), w jego ujęciu głównie ze względu na kwestie społeczno-finansowe. Inni badacze, jak np. Renata Konieczna-Woźniak, zwracają także uwagę na wymiary społeczno-kulturowe starości, takie jak status wieku i roli społecznej oraz kwestię norm, jakim podlegają ludzie na pewnym etapie życia (Konieczna-Woźniak 2012: 249). Niezależnie jednak od ujęcia czy przyjętej metodologii, tematyka ta otwiera nowe, interesujące obszary badawcze, stanowi wyzwanie dla wielu środowisk naukowych - od ekonomistów, przez historyków, literaturoznawców, aż po językoznawców.

Drugi już tom pod tytułem Ludzie starzy i starość na ziemiach polskich od XVIII do XXI wieku (na tle porównawczym) ${ }^{2}$ jest efektem prowadzonego w latach 2010 -2013 projektu badawczego sfinansowanego przez $\mathrm{NCN}^{3}$. Znalazło się w nim aż 29 ar-

Reklamowa TOP - Drukarnia Cyfrowa; Brudek, Paweł, Stanisława Steuden, Izabella Januszewska, Anna Gamrowska (red.) 2015. Oblicza starości we współczesnym świecie. T. 1: Perspektywa psychologiczno-medyczna. Lublin: Wydawnictwo KUL; Guzewicz, Monika, Stanisława Steuden, Paweł Brudek (red.) 2015. Oblicza starości we współczesnym świecie. T. 2: Perspektywa społeczno-kulturowa. Lublin: Wydawnictwo KUL; Halicka, Małgorzata, Jerzy Halicki, Joanna Borowik 2016. Niepełnosprawność i starość. Białystok: Wydawnictwo Uniwersytetu w Białymstoku; Małyska Aldona (red.) 2017. Starość: jej potencjał, trudy i wyzwania. Olsztyn: Centrum Badań Społecznych UWM: Katedra Teorii Wychowania UWM.

2 Janiak-Jasińska, Agnieszka, Katarzyna Sierakowska, Andrzej Szwarc (red.) 2016. Ludzie starzy i starość na ziemiach polskich od XVIII do XXI wieku (na tle porównawczym). T. 2: Aspekty społeczno-kulturowe. Warszawa: Wydawnictwo DiG. Wszystkie przypisy dotyczące recenzowanego tomu są zapisywane w postaci nazwiska autora artykułu i numeru stron, na których się on znajduje.

3 Opis projektu jest dostępny na stronie Ludzie starzy i starość na ziemiach polskich od XVIII w. do 1989 r. (na tle porównawczym): http://www.historia- 
tykułów, autorstwa badaczy z wielu ośrodków w Polsce - Polskiej Akademii Nauk, Uniwersytetu im. Adama Mickiewicza w Poznaniu, Uniwersytetu Gdańskiego czy też Uniwersytetu Jagiellońskiego - którzy są reprezentantami różnych dziedzin nauk humanistycznych i społecznych: literaturoznawstwa, psychologii, historii, socjologii, by wymienić jedynie kilka $\mathrm{z}$ nich. Redaktorzy zdecydowali się także na pewne uściślenie metodologiczne tytułu tomu drugiego, podkreślając jego aspekt społeczno-kulturowy, wokół którego mają oscylować tematy opublikowanych prac. W sposób naturalny rodzi się więc wątpliwość, czy mimo wszystko tak szeroko zakreślony temat pracy zbiorowej nie stanowi zagrożenia dla jej wewnętrznej spójności i merytoryczności?

W dotarciu do odpowiedzi na tak postawione pytanie może pomóc pogłębiona analiza przedstawionych $\mathrm{w}$ tomie artykułów. Redaktorzy podzielili je na dwie podstawowe podgrupy - Starość a zróżnicowanie społeczne oraz Ludzie starzy i starość - wizerunki, wyobrażenia, stereotypy $w$ dyskursie o starości. Tematyka 11 artykułów, które znalazły się w pierwszej grupie, oscyluje wokół społeczno-historycznego ujęcia kategorii starości. Znajdziemy w niej teksty dotyczące sytuacji duchownych w archidiecezji gnieźnieńskiej i poznańskiej (Witold Molik, s. 23-32) oraz księży (Krzysztof Lewalski, s. 33-52) i pastorów (Tadeusz Stegner, s. 53-64) żyjących w Królestwie Polskim, które pozytywnie wyróżniają się liczbą danych faktograficznych, przytoczonych statystyk i dokumentów źródłowych, także tych w języku niemieckim. Oczywiście artykuły te wzajemnie się uzupełniają i dopowiadają, ukazując pełniejszy obraz schyłku życia mężczyzn z określonej i w miarę jednorodnej grupy społecznej, którą niewątpliwie są

spoleczna.uw.edu.pl/projekt/starosc-i-ludzie-starzy [13.12.2017]. kapłani, niezależnie od obrządku, w jakim służą.

Dwa następne artykuły zdają się tylko pozornie podejmować inny temat, to jest życie profesorów krakowskich i wileńskich (Stefan Ciara, s. 65-72) oraz kondycję szlachetnie urodzonych wdów (Agnieszka Szudarek, s. 73-86). Udało się bowiem, dzięki tak skomponowanemu układowi, utrzymać ów charakter dopełnienia, dopowiedzenia, a także poszerzenia perspektywy. Obraz sytuacji stanu duchownego, przedstawiony w pierwszych tekstach tomu, można podsumować następująco - brak lub bardzo niskie emerytury, które nie pozwalają na leczenie i tak słabego zdrowia, stąd decyzja o kontynuowaniu pracy, mimo braku sił, do końca życia. Dlatego artykuł Stefana Ciary, również poświęcony życiu mężczyzn $\mathrm{w}$ podobnym okresie historycznym, nadto w podobnym przedziale wiekowym, ale już posiadających inne wykształcenie - wyższe - nabiera nowego kontekstu. Wspólna dla obu grup jest jedynie obawa o zdrowie, jednak jej źródła są inne, podobnie jak konsekwencje utraty sprawności zawodowej. Troska o podstawowe środki do życia, jaką wykazują księża, zostaje zastąpiona w przypadku naukowców obawą o ich spuściznę, o kontynuowanie rozpoczętych badań. Inaczej także kształtuje się sfera ekonomiczna obu grup - profesorowie troszczą się o zdrowie i podejmują próby polepszenia swojej kondycji, mają na to bowiem środki finansowe, stać ich zatem np. na wyjazdy do kurortów.

W podobne związki i zależności, wzajemne naświetlanie, dopełnianie kontekstów i dopowiadanie, wchodzą ze sobą także bohaterowie i bohaterki (a także całe grupy społeczne) pozostałych artykułów. Wnioski zbliżone do tych dotyczących księży i profesorów pojawiają się także w obrębie innych artykułów, czasami nawet bez bliskiego sąsiedztwa poszczególnych tekstów. Z całą 
pewnością sposób uporządkowania tak obszernego materiału dokonany przez redaktorów pozwala na dostrzeżenie dodatkowych zależności i mechanizmów. Dzięki zachowaniu ciągłości tematycznej, a także respektowaniu w pewnych miejscach chronologii historycznej, udaje się podkreślić największą wartość omawianego zbioru interdyscyplinarność.

Zdecydowanie większą część tomu zajmują teksty napisane przez literaturoznawców. Zestawienie ich prac z wynikami badań socjologów czy historyków pozwala na odkrycie siły literackich wyobrażeń i przedstawień, tej wyjątkowej paraleli z życiem. Gdy bowiem czyta się tekst Ewy Paczoskiej o Starych kobietach $w$ literaturze przełomu XIX i XX wieku (s. 209-2016), mając w pamięci wnioski płynące z badań Agnieszki Szudarek lub Katarzyny Sierakowskiej (s. 367-374), odnosi się nieodparte wrażenie, że literatura nie tylko opisuje to, co obserwujemy w życiu, ale także, dzięki odpowiedniej refleksji, powieść lub poezja potrafią odkryć przed nami pewne prawidłowości, czy może lepiej powiedzieć wprost: nierówności społeczne. Jeśli przyjąć, że najniżsi w hierarchii kościelnej księża mieli trudną sytuacją materialną i musieli pracować, mimo słabego zdrowia, do końca życia, jak w tym świetle jawi się sytuacja kobiet, które były pozbawione nawet możliwości posiadania stałej pracy?

W całym tomie autorzy przyglądają się starości jako zjawisku społecznemu, jako doświadczeniu jednostki lub grupy społecznej, pewnemu konstruktowi kulturowemu, rodzajowi opresji (w zależności od płci). Stawiają pytania o granice starości - czy dziś, tak jak kiedyś bywało, jest ona zależna od wieku? Czy obecnie królowa Wiktoria zostałaby uznana za starą w wieku 42 lat, tylko dlatego, że została wdową? A może starość zależy od pozycji społecznej? Czy pewne grupy starzeją się szybciej, inne wol- niej? Jak uchronić się od starczego zniedołężnienia? Już samo stawianie tych pytań zmusza czytelnika do ciągłej refleksji, do poszukiwania odpowiedzi wokół siebie, ale także we własnych wyobrażeniach.

Jak wynika bowiem $\mathrm{z}$ wielu badań przeprowadzonych przez socjologów, starość jest pojęciem względnym (Golinowska et al. 1999: 8-9), zależnym zarówno od tego, co społeczeństwo uznaje za jej oznakę (np. wdowieństwo), ale także od osobistego wyobrażenia własnej kondycji. I znowu ciekawe konkluzje wypływają z zestawienia wniosków socjologów z analizami literaturoznawców. Pod tym względem szczególnie interesujące są badania nad postaciami Wokulskiego i Rzeckiego, którzy, co może umknąć czytelnikowi w natłoku powieściowych wydarzeń, różnią się wiekiem zaledwie o kilka lat. Jednak sposób ukazania obu bohaterów jest diametralnie różny, co więcej, wypływa ze sposobu postrzegania samego siebie przez Rzeckiego, nie zaś z woli obiektywnego narratora jakoby przekonanego o starości jednego z bohaterów, a młodości drugiego. Najlepiej Rzeckiego poznajemy właśnie z jego osobistych zapisków, Pamiętnika starego subiekta. Tytułowy przymiotnik „stary” w świetle analizy przeprowadzonej przez Ewę Ihnatowicz (s. 195-208) zyskuje zupełnie nowy wymiar; badaczka pokazuje, że to Rzecki postrzega siebie jako osobę starą, która całe życie ma już za sobą, i dlatego nie powinna już niczego pragnąć, do niczego dążyć. Dzięki artykułom Urszuli Lehr i Dariusza Jarosza wiemy także, że tak narzucona świadomość siebie jako osoby starszej, i w związku z nią wycofywanie się z życia, są zjawiskami typowymi dla osób z pewnym bagażem doświadczeń. Może nie mieć to nic wspólnego $\mathrm{z}$ wiekiem, siła$\mathrm{mi}$ witalnymi, ale z przeżyciami osobistymi, a w związku z tym - wywierać negatywny wpływ zarówno na pojedyncze osoby, jak i całe grupy społeczne. Dostajemy jednak 
wskazówki, jakie działania systemowe można przedsięwziąć, aby temu przeciwdziałać.

W licznych artykułach tomu Ludzie starzy $i$ starość... zostaje także poruszony szeroko rozumiany problem cielesności osób starszych, a właściwie jej wykluczenia z obiegu kultury. Pojawiają się całe „obszary przemilczenia” (Agnieszka Rosales Rodriguez, s. 266):

Oglądanie starości nie jest bowiem, jak mogłoby się pozornie wydawać, oczywistym i nieodzownym aktem humanistycznego samopoznania człowieka, jako bytu nieustannie wędrującego ku śmierci. Starość wpisana w naturę, wszechobecna w społecznym porządku świata, jak zwykle wypychana na margines kultury wizualnej, niechętnie przyjmującej jej fizyczną postać (ibid.: 266).

O słuszności spostrzeżeń Rosales Rodriguez odnośnie do wykluczania z kultury wizualnej osób starszych można przekonać się, przeczytawszy inny artykuł z tego tomu. W tekście pt. Starość w polu widzenia. Sprawność i seksualność (s. 443-448) Iwona Kurz przytacza historię rzeźbiarki Louise Bourgeois, której zdjęcie przedstawiające siedemdziesięciojednoletnią autorkę $\mathrm{z}$ jedną z jej prac (dziewczynką w kształcie penisa) zostało ocenzurowane przez kuratora wystawy MoMA, ponieważ uznano je za pornograficzne (s. 443). Nadal pozostaje otwarte pytanie, czy oburzająca była sama rzeźba, czy jej połączenie ze starzej wyglądającą kobietą? Jak dowodzi autorka, erotyzm i ekspresja własnej seksualności u ludzi w pewnym wieku przestają być społecznie akceptowalne, a na potwierdzenie swojej tezy przywołuje programy i seriale telewizyjne, a także wspomina kontrowersje wokół pokazanej w telewizji nagości osoby starszej.

Problem seksualności osób starszych zostaje także poruszony przez Irenę Bilińską (s. 245-264). Badaczka opisuje wielką potrzebę zawarcia związku małżeńskiego, jaka właściwie przez całe życie towarzyszyła słowackiemu poecie okresu romantyzmu, Samo Bohdanowi Hroboniowi. Nie była ona jednak powodowana romantyczną wizją miłości, pragnieniem realizacji związku pokrewnych dusz, przeciwnie. Autorka zauważa, że w poezji Hrobonia „nie znajdziemy żadnego podziwu dla kobiety”, raczej jest ona traktowana jako „uzupełnienie dla mężczyzny" (s. 258), a jej zadaniem jest pomoc mężowi w problemach trawiących niezaspokojone seksualnie ciało. Temat ten był jednym z częściej poruszanych przez poetę w listach do jego przyjaciela Karla Slavoja Amerlinga, temu jednak nie w smak było analizowanie problemów natury tak intymnej, ponieważ uważał, że Hroboň jest już po prostu za stary na odczuwanie tego typu potrzeb (s. 256).

$\mathrm{W}$ tomie swoje miejsce znalazły także rozważania dotyczące wyglądu osób starszych. Analizie został poddany sposób, w jaki zazwyczaj przedstawiane są postaci w podeszlym wieku - siwa broda u mężczyzn, pomarszczona twarz u kobiet. Refleksje nad tym tematem prowadzą do kilku wniosków. Przede wszystkim wydaje się, że brakuje w literaturze nietypowych, wolnych od pewnych funkcji figuratywnych, postaci osób starszych. Najczęściej są to bowiem na poły abstrakcyjne byty, niepełnoprawni bohaterowie, którzy jedynie uosabiają tradycję, w literaturze XIX wieku - narodową, niepodległościową. Takie postaci pojawiają się po to, aby zaświadczyć swoim życiem o potrzebie wyznawania konkretnych wartości, są nośnikami pamięci i historii. Brakuje przedstawień w literaturze bohaterów i bohaterek w sędziwym wieku, wokół których toczyłaby się główna problematyka utworu. Postaci osób starszych pełnią jedynie określone funkcje względem głównych bohaterów, zazwyczaj znacznie 
młodszych (zwłaszcza zaś w literaturze dla dzieci i młodzieży), lub, jak w przypadku prozy pozytywistycznej, są egzemplifikacją pewnej tezy społecznej. Nadto ich starość nie wynika właściwie z konkretnego wieku, jest raczej wypadkową statusu społecznego, poziomu zamożności i wykształcenia, a także, na co zwraca uwagę Anna Landau-Czajka (s. 397-410), płci. W taki sposób tworzy się bardzo silnie zakorzeniony w kulturze obraz osoby starszej, która przestaje żyć dla siebie, czekając jedynie na możliwość spełnienia się w przestrzeni społecznej, najczęściej jako babcia lub dziadek. Urszula Jarecka charakteryzuje ten sposób przedstawienia starości jako „tradycyjny”, ukształtowany w XX wieku (s. 99).

Jak wynika z badań socjologów, owo literackie wyobrażenie tylko po części znajduje swoje odzwierciedlenie $\mathrm{w}$ rzeczywistości, niestety, jest także źródłem wielu napięć. Badania przeprowadzone przez Joannę Zalewską (s. 171-194) pokazują, że coraz większy odsetek osób na emeryturze, zwłaszcza $\mathrm{w}$ większych miastach, pragnie wykorzystać wreszcie osiągniętą wolność (ciesząc się owocami pracy całego życia) na samorealizację. Odkrywają oni nowe możliwości i formy spędzania wolnego czasu, które specjalnie dla nich przygotowują coraz liczniejsze placówki kulturalne. Często owa senioralna działalność jest także połączona z ponownym uświadomieniem sobie swoich potrzeb i możliwości seksualnych. Coraz częściej osoby starsze spędzają bowiem resztę swojego życia w pełni aktywnie, wymykając się tym samym narzucanym przez literaturę stereotypom babć i dziadków, których głównym celem życiowym jest opieka nad wnukami i przekazywanie wiedzy następnym pokoleniom.

Oczywiście w tomie odnajdziemy również inne artykuły opisujące sytuację osób na emeryturze $\mathrm{z}$ zupełnie innej strony samotności, odrzucenia, braku celu w ży- ciu. I na tym właśnie polega siła publikacji Ludzie starzy i starość..., że dzięki zróżnicowaniu zakresu tematycznego oraz przyjętych metodologii jesteśmy w stanie dostrzec dość szerokie spektrum danego problemu, w tym przypadku - związku życia z literaturą, jej siły oddziaływania na nasze wyobrażenie o rzeczywistości.

Jak się bowiem okazuje, dziś już nie tylko powieść kształtuje społeczne wyobrażenia o osobach starszych; w dużej mierze ta rola została przejęta przez prasę kolorową oraz telewizję. Kilka prac zamieszczonych w omawianym tomie jest poświęconych właśnie tej tematyce, jak chociażby Starość w reklamie (Agnieszka Janiak-Jasińska, s. 353-366) oraz Wizerunki starości na łamach polskiej prasy kobiecej dwudziestolecia międzywojennego (Katarzyna Sierakowska, s. 367-374). Poddają one analizie sposób przedstawiania osób starszych, częstotliwość ukazywania się takich postaci w mediach, a także kontekst, w jakim one występują.

Już z samej analizy tematyki artykułów tomu drugiego Ludzi starych i starości... widać, że w kręgu zainteresowań badaczy znalazł się niezwykle szeroki zakres zagadnień dotyczących różnych aspektów tytułowej problematyki. Wydaje się, że na ową kompleksowość ujęcia tematu, zwłaszcza jeśli rozpatrywać recenzowaną publikację w perspektywie całości, zatem zarówno tomu pierwszego, jak i drugiego, miało znaczący i pozytywny wplyw to, że wiele $\mathrm{z}$ badań zostało przeprowadzonych $w$ ramach finansowania projektu przez NCN. Pozwoliło to na dotarcie do dokumentów archiwalnych, zarówno polskich, jak i zagranicznych, co zaowocowało naprawdę imponującym dostępem do informacji. Nadto określenie ram czasowych tomu w przedziale od XVIII do XXI wieku pozwala na uchwycenie ewolucji całego spektrum zjawisk współczesnego świata, jak chociażby tych inicjowanych 
przez zmiany $\mathrm{w}$ prawie (wprowadzenie emerytur dla różnych grupy społecznych), które przełożyły się na poprawę jakości życia księży i wdów.

Umieszczenie w jednym tomie artykulów tak różnych pod względem metodologii badawczej, kręgu zainteresowania, a także analizowanej epoki, nie działa na niekorzyść publikacji. Dzieje się tak, ponieważ dwie perspektywy znalazły swoje miejsce w każdej pracy. Oczywiście nadrzędny temat starości i osób starszych, ale także doprecyzowanie kwestii geograficznej, tzn. oscylowanie wokół zjawisk zachodzących na ziemiach polskich. Nie jest zatem tak, jak czasami zdarza się $\mathrm{w}$ innych zbiorowych opracowaniach, że temat wydaje się nieprzystający do zasadniczej części publikacji, nie oddaje jej ducha lub znajdują się w nim artykuły wymykające się ustalonemu zakresowi. Zatem na pytanie postawione na początku tej refleksji - czy tak szeroko zakreślony temat pracy zbiorowej jest zagrożeniem dla jej wewnętrznej spójności i merytoryczności? - można śmiało odpowiedzieć negatywnie. Nie wydaje się, aby temat tomu był określony zbyt obszernie, przeciwnie, cechuje się on precyzją i adekwatnością, uwzględnia całą różnorodność pomieszczonych tam prac. Czytelnik nie ma zatem poczucia braku integralności, a raczej nieustannego zaskoczenia, jak szerokie spektrum zagadnień, które mogą $\mathrm{w}$ pierwszym odruchu zupełnie nie kojarzyć się z podjętą tematyką, wpisuje się w tytułowy problem.

To, co także pozytywnie wyróżnia ową publikację, to fakt, że w większości artykułów udało się uniknąć tego, co Łukasz Łotocki nazywa „tabu językowym”:

Tabu językowe starości podszyte jest prawdopodobnie strachem przed starością, uznawaniem jej za coś „niewłaściwego”, obcego, krępującego itp. Innymi słowy starość nie jest traktowana - również przez bada- czy tego zagadnienia - jako naturalna faza życia (jak np. młodość), o której możemy swobodnie mówić i pisać, ale jako faza życia obciążona ciężarem symbolicznym; faza, o której trzeba pisać delikatnie, ważąc słowa, tak aby nikogo nie urazić (Łotocki 2012: 132).

Praca Ludzie starzy i starość... jest interesująca także jako publikacja ogólnie humanistyczna, zwracająca uwagę na konkretną grupę społeczną, która w dzisiejszym świecie zdaje się wykluczana z głównego nurtu kultury. Wspaniale została ukazana zależność między tym, co literackie, a tym, co historyczne i socjologiczne, uchwycono też wzajemny wpływ, jaki wywierają na siebie te dyscypliny, będące przecież w istocie jedynie próbą ujęcia w naukowe ramy naszego życia. Dlatego, co nie jest częste $\mathrm{w}$ przypadku tego typu wydawnictw, to może być czytane z prawdziwą pasją i zaciekawieniem, odkrywa bowiem przed czytelnikiem być może nieznaną do tej pory problematykę, otwiera nas na powszechnie ważne, dotyczące każdego człowieka zagadnienia. Biorąc pod uwagę, jak obszerne są oba tomy Ludzi starych i starości..., należy szczególnie podkreślić wysoki poziom merytoryczny właściwie wszystkich studiów. Brakuje może jedynie obszerniejszego artykułu wstępnego, który pozwoliłby na dookreślenie zakresu badań, doprecyzował pewne założenia, usystematyzował pojęcia. Redaktorzy tomu zdecydowali się opatrzyć go wprowadzeniem, które jednak jest jedynie krótką prezentacją treści poszczególnych rozpraw.

Z każdym dziesięcioleciem wydłuża się przeciętna długość życia człowieka. Jeszcze nigdy nie żyło na świecie tylu stulatków, ilu żyje obecnie. Poznanie właśnie tej grupy społecznej wydaje się zatem ważnym zadaniem nie tylko dla historyków i socjologów, ale także literaturoznawców. Kto inny bo- 
wiem ma tyle wolnego czasu na czytanie, ile właśnie człowiek na emeryturze?

\section{Bibliografia}

Golinowska, Stanisława, Jerzy Holzer, Halina Szwarc, Wojciech Pędich 1999. „Starzenie się i starość: pojęcia, tendencje, cechy i struktury". W: Stanisława Golinowska (red.). Ku godnej aktywnej starości. Raport o rozwoju spotecznym. Warszawa: UNDP.

Janiak-Jasińska, Agnieszka, Katarzyna Sierakowska, Andrzej Szwarc (red.) 2016. Ludzie starzy i starość na ziemiach polskich od XVIII do XXI wieku (na tle porównaw- czym). T. 2: Aspekty spoteczno-kulturowe. Warszawa: Wydawnictwo DiG.

Jarecka, Urszula 2002. „Starość w mediach konteksty, tendencje i przemilczenia”. Kultura wspótczesna. Teoria, interpretacja, praktyka 1-2: 98-113.

Konieczna-Woźniak, Renata 2012. „Odmłodzona starość - implikacje podmiotowe i społeczne". Studia Edukacyjne 21: 249-262 .

Łotocki, Łukasz 2012. „Barwy jesieni życia. O społeczno-kulturowym obrazie starości". Problemy Polityki Spotecznej 17: 131-146.

Pikuła, Norbert G. 2015. Poczucie sensu życia osób starszych. Inspiracje do edukacji w starości. Kraków: Oficyna Wydawnicza Impuls. 